\title{
An Appraisal of Public Pension Reserve Funds Management - Evidence From Portugal
}

\author{
Maria Teresa Medeiros Garcia
}

\begin{abstract}
ISEG (Lisboa School of Economics and Management), Universidade de Lisboa, Rua do Quelhas, 6, 1200-781 Lisboa, Portugal UECE (Research Unit on Complexity and Economics), Rua Miguel Lupi, 20, 1249-078 Lisboa, Portugal

Email: mtgarcia@iseg.utl.pt
\end{abstract}

Doi:10.5901/mjss.2014.v5n23p333

\begin{abstract}
The creation of a public pension reserve fund is one of the reform measures that many countries implemented in order to guarantee the long term viability of existing government-operated pension systems. However, this measure raises the issue of the need to ensure sound management of those pension funds. This article focuses on the experience of the Portuguese public pension reserve fund and on the role it should accomplish in helping to finance the rising cost of public pensions.
\end{abstract}

Keywords: social security system, public pension reserve fund, reforms, management

\section{Introduction}

The partial prefunding of the otherwise pay-as-you-go system by the establishment and further development of a public pension reserve fund, involves an analysis of governance mechanisms and investment controls as a means of evaluating the sound management of the fund (Yermo, 2008; Stewart and Yermo, 2010). Only a credible and large-funded component pension system may enhance growth, facilitating financial intermediation and long-term investment. If the fund results in an increase of government spending and deficits, or if the fund is allocated exclusively to public investment, then national saving does not increase and some of the potential private capital market development is lost. The danger is that building up reserves for paying off the pension debt in later years might make things worse. The proposal of investing part of the trust funds in private bonds and equities, rather than solely in federal debt was discussed by Diamond (1996).

In Portugal, the government introduced partial public capitalisation in 1989, with the creation of the public pension reserve fund (FEFSS - Fundo de Estabilização Financeira da Segurança Social). Capitalisation comprises the investment, at compound interest rates, of the surplus of the benefit system, net of management and acquisition charges, in order to obtain, by a given date, the amount of capital necessary to guarantee the payment of pensions for two years.

The move from an unfunded, to a more actuarial system, requires an analysis of the various aspects related to efficiency, distribution, and stability (Lindbeck and Persson, 2003), as well as risk and risk sharing issues, administrative costs, and profitability. Indeed, the investment policies of fund managers strongly influence the allocation and productivity of capital, with important effects on the economy and on adequate retirement income and replacement rates (World Bank, 1994). However, publicly managed funds are often required to invest in government securities, which imposes a hidden tax on contributing employees.

This paper examines the architecture of the government-operated pension system in Portugal. An appraisal of the public pension reserve fund is presented, bringing attention to the governance structure and investment policy performance. Finally, some concerns and conclusions are discussed.

\section{The Architecture of Government-Operated Pension System}

In 1984, a system of obligatory Social Security insurance was created, whereby the active working population was made responsible for the financing of pensions paid out under the Social Security Law.

The debate about the long term financial viability of the existing government-operated pension system motivated the introduction of partial public capitalisation in 1989, with the creation of the public pension reserve fund. Since then, the surplus of the benefit system was supposed to be transferred to this fund for investment in financial markets.

During the last two decades, several other pension reforms took place. Indeed, both the major concern about the burden for future generations and the increase in pension expenditure, explain the further important changes that took 
place in 2000, 2002, and 2007. Even so, cuts are envisaged as a result of the 2008 crisis and the recent financial bailout of Portugal, which will certainly have regressive effects (Heise and Lierse).

The Social Security Law of 2000 explicitly considers and reinforces partial capitalisation, stipulating that there must be a transfer into the reserve fund of an amount of between two and four percent of the employees' contributions, up to the level whereby total pensions expenditure is ensured for a minimum period of two years, in addition to the transfer of any annual surplus from the benefit system. The objective of this measure was to ensure the financial viability (sustainability) of the Social Security system. Silva et al. (2004) analysed the accounts of the benefit sub-system, as well as its impact on the portfolio of the public pension reserve fund. They estimated that the trust fund would be exhausted by 2026, after reaching a peak in 2012, if the features of the system remained the same.

The Social Security Law of 2002 also considered a diversification and enlargement of the financing sources of the system and introduced parametric changes: namely that it reduced benefits by changing the benefit rules in an actuarial direction and gave a more prominent role to the complementary pension system. The old age pension benefit formula was changed in order to take into account life-time wages, although transition clauses have considerably delayed the full introduction of this change. The previous old pension formula (based on a flat accrual rate of $2 \%$, full length of service (40 years), and a reference wage based on the best 10 years' monthly wages out of the final 15 years) allows a maximum gross replacement rate of $80 \%$. In the new formula, annual accrual rates are set according to the level of wages declared (decreasing between $2.3 \%$ and $2 \%$ ). This only applies to pensioners with more than 20 years of contributions. For all the other pensioners, a flat accrual rate of $2 \%$ is still applied (Decree-Law $n^{0} 35 / 2002$, 19th February). For all contributors with a contributory career of at least 15 years as of January, 2002, and for all contributors retiring by 2017, the best pension out of three different benefit formulas is assured: the old benefit formula, the new formula, and a proportional one. For all those other members of the workforce with contributions registered before January 2002, the formula that grants a higher pension - the new formula or the proportional one - is applied. This reform was expected to improve compliance within the system, as well as act as an incentive for older employees to stay on longer in the workforce.

The recently approved Social Security Law of 2007 introduces a sustainability factor in the benefit calculation formula which is related to the evolution of average life expectancy, in order to ensure financial sustainability of the system in the face of adverse demographic and economic changes. On the other hand, it also establishes that the complementary system includes a public regime of capitalisation and complementary individual and collective systems. Indeed, in February 2008, retirement certificates (Certificados de Reforma) were established as the public regime of capitalisation. They are voluntary and for individual adhesion. In December 2011, the reference value was $1.08710 €$ and the fund value (the FCR - Fundo de Certificados de Reforma - is managed by the same State entity that manages the public pension reserve fund) was $19,990,439.64 €$. The contribution rate is between $2 \%$ and $4 \%$ of the employee's salary. At the end of 2009, there were 7,425 adherents. On the other hand, the complementary individual and collective systems include professional and individual private pension plans. The characterisation of these regimes is presented in Garcia $(2004,2006)$.

In this changing environment, Garcia and Lopes (2009) emphasize that the parametric reforms to the existing PAYG, combined with the reserve fund, ensure its financial sustainability. On the other hand, the impact of a systemic reform, such as the adoption of a fully pre-funded system, on a range of macroeconomic variables, is very negative. Thus, this is not a viable option for policymakers when redesigning a Social Security pension system. Orenstein (2013) analyses the process known as "pension privatisation", from 1981 to 2004.

In addition to these major reforms, some other adjustment took place within the public sector pension system, with the objective of eliminating their differing approaches. Hence, real convergence was established, firstly in 1993 (DecreeLaw 286/93, 20 ${ }^{\text {th }}$ August) with the approval of a new pension formula calculation for new public employees since the $1^{\text {st }}$ of September, 1993, which is identical to the one adopted by the benefit system of the Social Security system, and recently, in 2005 (Law 60/2005, 29th December). With the latter, eligibility requirements as well as pension formula calculation, are progressively identical to those of the private sector.

Thus, at present, the eligibility requirements for old age pensions are the following: the minimum age for old age pensions for both men and women is 65 (since 1999: Decree-Law 9/99, $8^{\text {th }}$ January), with an exception for the public sector, where the minimum age is 60 , or after 36 years of service, whichever is reached first (this requirement has changed since 2003, meaning that since then both 60 years of age and 36 years of service must be fulfilled together), up until 2005. The minimum number of contributory years is 15 (since 1993: Decree-Law 329/93, 25th September) and 5 for the public sector, up until 2005. Finally, eligibility for early-retirement pensions starts at 55 years of age, as well as 30 years of contributions, with a annual penalty of 4.5\% between January 1999 (Decree-Law 9/99) and May 2007 (DecreeLaw 187 ), and of 6\% since May 2007 up to the present. For the public sector, the indexation scheme is related to public employees' wages up until 2005. Conversely, the indexation scheme is ad hoc for the private sector. For the private 
sector scheme, the pension formula is calculated by: $P_{t}=x \frac{N}{D} w_{\text {reft }} \frac{L E_{2006}}{L E_{\text {year }-1}}$, where $\mathrm{P}$ is the pension benefit, $\mathrm{x}$ is the legal replacement rate, $\mathrm{N}$ is the number of years of contributions, $\mathrm{D}$ is the maximum number of years of contributions taken into account, $w_{r e f_{i}}=\sum_{i=0}^{T}\left(w_{t-i} /\right.$ index $\left._{t-i}\right)$ is the reference salary, where index is the indexation rule for past earnings taken into

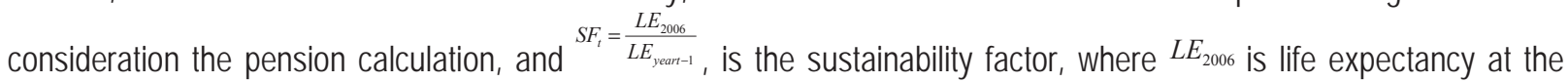
age of 65 in 2006, and $L E_{\text {yeart }-1}$ is life expectancy at the age of 65 in the year prior to that for which pension benefit is calculated. Before 2002, the base period for the calculation of the reference salary $(T)$ was the highest 10 years' salaries over the final 15 years (after the reform of 2002, this will become average lifetime salaries by 2035), with $x=80 \%$ and $D$ $=40$ years. For civil servants, the base is the final salary for those who started working prior to September 1993, with $x=$ $100 \%$ (since $2004, x=90 \%$ ) and $D=36$ years, after that date they are subject to the same rules as those of the private sector scheme. There is no ceiling and the indexation rule for past earnings is the price index.

Finally, the statutory contribution rate is $34.75 \%$ for the private sector scheme ( $11 \%$ being the employee's contribution, and $23.75 \%$ is contributed by the employer). Of this rate, approximately two thirds goes towards the payment of pensions of all types. Public employees paid a contribution rate of $10 \%$ up until 2011. Since 2011, their contribution rate has increased to $11 \%$.

Summing up, the pension system in Portugal includes three pillars. With regards to first pillar pensions, Portugal offers a universal State pension regime, which is means-tested, and labour-market-based public pension schemes. All of them are mandatory for employees of the private sector and the public sector, as well as the self-employed. They are pay-as-you-go schemes and State budget financing is applied in the case of the already closed public sector pension scheme (since 2005). The convergence between them is notable. The second pillar is not mandatory, except for some workers of the private sector (namely the banking and insurance sectors). The third pillar pension schemes are not mandatory.

The following section describes the Portuguese reserve fund and considers its governance structure, restrictions and mandates, as well as the portfolios observed.

\section{The Public Pension Reserve Fund}

Many countries choose to prefund their pension obligations. Partially funded defined benefit schemes is the most common form of publicly mandated pension schemes with some degree of prefunding (Iglesias and Palacios, 2000).

The accumulation of significant reserves by a large number of public pension schemes around the world will probably reduce the risk of future governments not being able to meet pension obligations. Therefore, the management of these funds has a direct effect on financial sustainability and potential benefit levels. In addition, it also has important indirect effects on the overall economy, especially when the funds are large in relation to domestic capital markets.

The discussion about how these funds are governed and invested is very important, as is that about how their returns compare to relevant benchmarks.

Iglesias and Palacios (2000) find that public pension funds are subject to a series of restrictions and mandates that produce poor returns. Often the non-pension objectives of the government lead to social and targeted investments and forced loans to the government to finance its deficit. Poor governance is the major cause of bad returns.

Indeed, in the past, most public pension funds have not been invested effectively, largely because of political interference. Palacios (2002) reviews strategies for limiting risks that arise when a public entity is entrusted with managing national pension savings. In particular, an attempt is made to draw lessons from recent reforms in five OECD countries (Canada, Ireland, Japan, New Zealand, and Sweden).

A large body of the literature asserts the importance of governance on the performance of public pension funds. For example, Impavido (2002) surveys the empirical literature on the relationship between governance of public pension fund management and investment performance. Furthermore, it attempts to identify good governance practices and guidelines aimed at reducing political risk usually associated with public pension fund management. Results indicate that governance (ability to isolate fund management from political intervention) determines key investment strategies which, in turn, affect performance. Moreover, several statements are cited which guarantee good performance:

- The sole objective of public pension funds should be to provide affordable and sustainable retirement income;

- Governors should be independent from political power and fit and proper for their role;

- The law of fiduciary duty should define the responsibilities of governors; 
- Governors should be made accountable for the performance of the fund;

- Independent performance evaluations (investment, audit, actuarial, and other) should be conducted by external and independent entities on a regular basis;

- Outside experts should be used regularly during the definition and implementation of fund policies; and

- Internal controls should be established to avoid conflicts of interest.

Vittas et al. (2008) present the experience of four new public pension funds that were created in Norway, Canada, Ireland, and New Zealand. These countries promoted a modern framework for efficient investment performance by emphasizing strong fund governance structures and public accountability and transparency. Also, Yermo (2008) analyses the main Social Security reserve funds: SSRFs and sovereign pension reserve funds, plus SPRFs in OECD countries, focusing on the reserve funds of the following countries: Canada, France, Ireland, Japan, Korea, New Zealand, Norway and Sweden. More recently, Stewart and Yermo (2010) emphasize the essential importance of ensuring good governance of reserve funds in order to meet their goal of financing public pension systems. In addition, they suggest avenues for strengthening the governance and management of the Japanese Government Pension Investment Fund (GPIF), the largest single pool of pension assets in the world.

The Portuguese public pension reserve fund (the so-called Social Security Financial Stabilisation Fund), as previously mentioned, was established in 1989 and, by December 2011, it had 8,872.45 million Euros in assets, which is equivalent to $5.1 \%$ of GDP (the FEFSS is ranked among the largest European pension funds). The public pension reserve fund is managed by a State institution, the IGFCSS (Instituto de Gestão de Fundos de Capitalização da Segurança Social), which was set up in 1999. The sources of financing are both benefit system surpluses and a percentage of between $2 \%$ and $4 \%$ of obligatory contributions paid by employees to the Social Security system, until the level of assets of the fund attains the equivalent value of two years of Social Security benefits. An analysis is made below of its role and composition (the channeling of these surpluses into the reserve fund is not always straightforward), as well as the crucial aspects of governance and investment.

The IGFCSS is established as an entity within the public administration, which is specialised in asset management with medium and long term investment objectives. The first annual report dates from 2001. Annual reports from after 2009 are not available (more recent data is available from the Report of Social Security Accounts, 2010-2011, IGFSS).

A large amount of legislation has been passed regarding both the public pension reserve fund and the corresponding management entity, which contributes to a lack of transparency (see Table 1).

Table 1. Legislation, 1989-2012

\begin{tabular}{|c|c|c|c|c|c|c|c|c|c|c|c|c|c|}
\hline Year & 1989 & 1999 & 2000 & 2002 & 2004 & 2007 & 2007 & 2008 & 2008 & 2010 & 2011 & 2011 & 2012 \\
\hline Measures & $\begin{array}{c}\text { Creation } \\
\text { of } \\
\text { FEFSS }\end{array}$ & $\begin{array}{c}\text { Creation of } \\
\text { IGFCSS } \\
\text { Establishes } \\
\text { the } \\
\text { IGFCSS } \\
\text { statutes, } \\
\text { namely } 3 \\
\text { governing } \\
\text { bodies }\end{array}$ & \begin{tabular}{|c|}
$\begin{array}{c}\text { Statutes } \\
\text { of FEFSS }\end{array}$ \\
\end{tabular} & $\begin{array}{l}\text { Changes } \\
\text { to the } \\
\text { statutes of } \\
\text { FEFSS: } \\
\text { the } \\
\text { creation } \\
\text { of the } \\
\text { strategic } \\
\text { reserve }\end{array}$ & $\begin{array}{c}\text { Changes to } \\
\text { the statutes } \\
\text { of FEFSS: } \\
\text { more } \\
\text { detailed } \\
\text { asset } \\
\text { composition, } \\
\text { increasing } \\
\text { the } \\
\text { maximum } \\
\text { investment } \\
\text { in equities to } \\
25 \%\end{array}$ & $\begin{array}{l}\text { Changes } \\
\text { to } \\
\text { IGFCSS } \\
\text { statutes }\end{array}$ & \begin{tabular}{|c|} 
Changes to \\
IGFCSS \\
statutes: \\
establishes 3 \\
departments \\
Investments; \\
Studies, \\
Planning and \\
Control; \\
Management \\
Support)
\end{tabular} & \begin{tabular}{|c|}
$\begin{array}{c}\text { Creation } \\
\text { of FCR }\end{array}$ \\
\end{tabular} & \begin{tabular}{|c|} 
Statutes \\
of FCR
\end{tabular} & $\begin{array}{c}\text { Changes } \\
\text { to } \\
\text { IGFCSS } \\
\text { statutes }\end{array}$ & $\begin{array}{c}\text { Changes } \\
\text { to } \\
\text { IGFCSS } \\
\text { statutes }\end{array}$ & $\begin{array}{l}\text { New Law } \\
\text { of the } \\
\text { New } \\
\text { Ministry of } \\
\text { Solidarity } \\
\text { and } \\
\text { Social } \\
\text { Security }\end{array}$ & $\begin{array}{c}\text { Changes } \\
\text { to } \\
\text { IGFCSS } \\
\text { statutes }\end{array}$ \\
\hline Legislation & \begin{tabular}{|c|}
$\mathrm{DL}$ \\
$259 / 89$, \\
14 \\
August
\end{tabular} & $\begin{array}{c}\text { DL 449- } \\
\text { A/99, } 4^{\text {th }} \\
\text { November }\end{array}$ & \begin{tabular}{|c|} 
Portaria \\
$375 / 2000$, \\
$26^{\text {th }}$ June
\end{tabular} & \begin{tabular}{|c|} 
Portaria \\
$1557-$ \\
B/2002, \\
$30^{\text {th }}$ \\
December
\end{tabular} & $\begin{array}{c}\text { Portaria } \\
1273 / 2004, \\
7^{\text {th }} \text { October }\end{array}$ & \begin{tabular}{|c|} 
DL \\
$216 / 2007$, \\
$29^{\text {th }}$ May
\end{tabular} & \begin{tabular}{|c|} 
Portaria \\
$640 / 2007,30$ \\
May
\end{tabular} & \begin{tabular}{|c|}
$\mathrm{DL}$ \\
$26 / 2008$, \\
$22^{\text {nd }}$ \\
February
\end{tabular} & \begin{tabular}{|c|} 
Portaria \\
212 \\
12008 \\
29 \\
February \\
\end{tabular} & $\begin{array}{c}\text { Portaria } \\
1329- \\
\text { D/2010, } \\
30 \\
\text { December } \\
\end{array}$ & \begin{tabular}{|c|}
$\mathrm{DL}$ \\
$39 / 2011$, \\
$21 \mathrm{st}$ \\
March \\
\end{tabular} & $\begin{array}{c}\mathrm{DL} \\
126 / 2011, \\
29^{\text {th }} \\
\text { December }\end{array}$ & $\begin{array}{c}\text { DL } \\
203 / 2012 \\
28 \\
\text { August }\end{array}$ \\
\hline
\end{tabular}


Table 2. Mandates of the Board of Directors and Annual Reports, 2001-2009

\begin{tabular}{|c|c|c|c|c|c|c|c|c|c|}
\hline & 2001 & 2002 & 2003 & 2004 & 2005 & 2006 & 2007 & 2008 & 2009 \\
\hline $\begin{array}{l}\text { President of the } \\
\text { Board of Directors }\end{array}$ & $\begin{array}{c}\text { Joel Hasse } \\
\text { Ferreira }\end{array}$ & $\begin{array}{c}\text { Pedro Alves } \\
\text { Guerra }\end{array}$ & $\begin{array}{c}\text { Pedro Alves } \\
\text { Guerra }\end{array}$ & $\begin{array}{l}\text { Pedro } \\
\text { Alves } \\
\text { Guerra }\end{array}$ & $\begin{array}{c}\text { Manuel Pedro } \\
\text { Baganha }\end{array}$ & $\begin{array}{c}\text { Manuel Pedro } \\
\text { Baganha }\end{array}$ & $\begin{array}{l}\text { Manuel Pedro } \\
\text { Baganha }\end{array}$ & $\begin{array}{l}\text { Manuel Pedro } \\
\text { Baganha }\end{array}$ & $\begin{array}{c}\text { Manuel } \\
\text { Pedro } \\
\text { Baganha }\end{array}$ \\
\hline Annual Reports & PT & PT & PT & PT & PT & PT & PT & PT & PT \\
\hline $\begin{array}{l}\text { Statutory Audit } \\
\text { Certification }\end{array}$ & $\begin{array}{c}\text { Figueiredo, } \\
\text { Neves \& } \\
\text { Associado }\end{array}$ & $\begin{array}{c}\text { Figueiredo, } \\
\text { Neves \& } \\
\text { Associado }\end{array}$ & $\begin{array}{l}\text { Figueiredo, } \\
\text { Neves \& } \\
\text { Associado }\end{array}$ & KPMG & KPMG & Delloitte & Delloitte & Delloitte & Delloitte \\
\hline Facts \& Figures & & ENG & ENG & ENG & ENG & ENG & ENG & ENG & ENG \\
\hline Awards & & & & & $\begin{array}{l}\text { "Committed to } \\
\text { Excellence in } \\
\text { Europe" }\end{array}$ & $\begin{array}{l}\text { "Best Pension Fund } \\
2006 \text { in Portugal" } \\
\text { by IPE - } \\
\text { Investments \& } \\
\text { Pensions Europe }\end{array}$ & $\begin{array}{l}\text { Management } \\
\text { System } \\
\text { Certification by } \\
\text { APCER and } \\
\text { IONet }\end{array}$ & $\begin{array}{l}\text { Management } \\
\text { System } \\
\text { Certification by } \\
\text { APCER and } \\
\text { IONet }\end{array}$ & \\
\hline
\end{tabular}

The principal mission of IGFCSS is the management, through capitalisation, of the public pension reserve fund portfolio (FEFSS). Additionally, the Social Security Law of 2002 allows for the IGFCSS to not only carry out the portfolio management of the FEFSS, but also to extend its activity to the management of complementary systems. This was explicitly considered even further in the new law of 2007 (as mentioned, in 2008, retirement certificates were established and their respective fund is the FCR). The organisation structure is composed of three boards: the Supervisory Council (with three members), the Advisory Board (with nine members) and the Board of Directors (with three members). The latter includes four departments, the Financial Investments Department, the IT Department, the Administrative and Accounts Department and the Control and Planning Department and is responsible for producing the Annual Report (see Table 2). The Board of Directors is responsible for formulating investment policy, setting strategic asset allocation and supervising management.

The asset allocation regulation has experienced changes regarding maximum legal limits (see Table 3) and includes the following assets classes:

- Government securities or others guaranteed by the Portuguese State;

- Bonds and commercial certificates;

- Shares, securities and other similar investments in listed companies;

- Investment units in real estate and security funds;

- Real estate;

- Deposits and other short term applications of capital;

- Interest receivable from deferrals and accruals.

Table 3. Asset Allocation Legal Limits, 2000 and 2004

\begin{tabular}{|c|c|c|c|c|c|}
\hline \multirow{2}{*}{\multicolumn{2}{|c|}{ Asset Classes }} & \multicolumn{2}{|c|}{2000} & \multicolumn{2}{|c|}{2004} \\
\hline & & Minimum & Maximum & Minimum & Maximum \\
\hline \multicolumn{2}{|l|}{ Debt guaranteed by the Portuguese State } & $50 \%$ & $100 \%$ & $50 \%$ & $100 \%$ \\
\hline \multicolumn{2}{|c|}{$\begin{array}{l}\text { Other Debt not guaranteed by the Portuguese State, } \\
\text { with 'BBB-/Baa3' rating or higher (investment grade) }\end{array}$} & $0 \%$ & $50 \%$ & $0 \%$ & $40 \%$ \\
\hline \multicolumn{2}{|l|}{ Equities traded in OECD regulated markets } & $0 \%$ & $20 \%$ & $0 \%$ & $25 \%$ \\
\hline \multicolumn{2}{|l|}{ Mixed Mutual Fund Shares } & $0 \%$ & $20 \%$ & $0 \%$ & $10 \%$ \\
\hline \multicolumn{2}{|l|}{ Real Estate } & $0 \%$ & $30 \%$ & $0 \%$ & $10 \%$ \\
\hline \multicolumn{2}{|l|}{ Strategic Reserve } & - & - & & $5 \%$ \\
\hline \multicolumn{2}{|l|}{ Exposure to currency risk } & - & - & $0 \%$ & $15 \%$ \\
\hline \multirow{2}{*}{$\begin{array}{l}\text { Diversification - Securities issued by the } \\
\text { same entity or operations performed with } \\
\text { the same counterpart }\end{array}$} & Fund & $0 \%$ & $10 \%$ & $0 \%$ & $5 \%$ \\
\hline & Equity & $0 \%$ & $20 \%$ & $0 \%$ & $20 \%$ \\
\hline Use of derivatives & \multicolumn{5}{|c|}{$\begin{array}{l}\text { Only for hedging purposes or for the efficient management of the portfolio, specificall, } \\
\text { for non-leveraged replication of the returns on the underlying assets }\end{array}$} \\
\hline
\end{tabular}

The investment policy followed by the management board of IGFCSS must guarantee capital preservation, for which it 
must obtain a growth rate at least equal to the expected inflation rate for the Euro zone. The public pension reserve fund is considered an instrument of public capitalisation.

In addition, the IGFSS assumes the role of an entity which is responsible for the efficient management of public pension reserves, with the objective of supplying a competitive asset management service that ensures a public alternative of capitalisation. The IGFCSS must respect the following investments restrictions:

- All assets must be denominated in Euros;

- At least $50 \%$ of the total assets must be invested in debt which is guaranteed by the Portuguese State;

- Equity investment must not exceed $25 \%$ of total assets;

- All of the bonds held in the portfolio must have a minimum rating of BBB/Baa2 (however, the Board of Directors has decided to restrict its investments to assets with a rating of not lower than $A / A 3$ );

- Investment in mutual fund units must not exceed $10 \%$ of total assets.

Table 4 shows the evolution of the value of the reserve pension fund portfolio. By 2009 this value reached a peak of accumulated assets of $9,407.66$ million Euros, which corresponded to $97.8 \%$ of annual pension benefits expenditure (or 11.74 months, still below the objective of two years of Social Security benefits). This represented 5.8\% of GDP.

Table 4. Value of the Fund Portfolio

\begin{tabular}{lccccccccccc}
\hline & 2001 & 2002 & 2003 & 2004 & 2005 & 2006 & 2007 & 2008 & 2009 & 2010 & 2011 \\
\hline Total value (million Euros) & $3,798.64$ & $4,699.42$ & $5,428.31$ & $5,779.05$ & $6,176.17$ & $6,640.09$ & $7,560.24$ & $8,338.88$ & $9,407.66$ & $9,637.95$ & $8,872.45$ \\
\hline \multirow{2}{*}{$\begin{array}{l}\text { \% of annual total pension } \\
\text { payments }\end{array}$} & $77 \%$ & $72.5 \%$ & $79.9 \%$ & $80.1 \%$ & $80.7 \%$ & $86.2 \%$ & $95.1 \%$ & $97.8 \%$ & $93.1 \%$ & $85.71 \%$ \\
& $2 / 3 \%$ & 9.2 & 8.7 & 9.6 & 9.6 & 9.7 & 10.3 & 11.41 & 11.74 & 11,16 & 10,29 \\
\% of GDP & & months & months & months & months & months & months & months & months & months & months \\
\hline
\end{tabular}

Source: Instituto de Gestão de Fundos de Capitalização da Segurança Social, Annual Reports (2001-2009); Conta da Segurança Social, 2010-2011.

However, the transfer of benefit system surpluses to the public pension reserve funds has not been made on a regular basis (Figure 1), which might be a cause for concern.

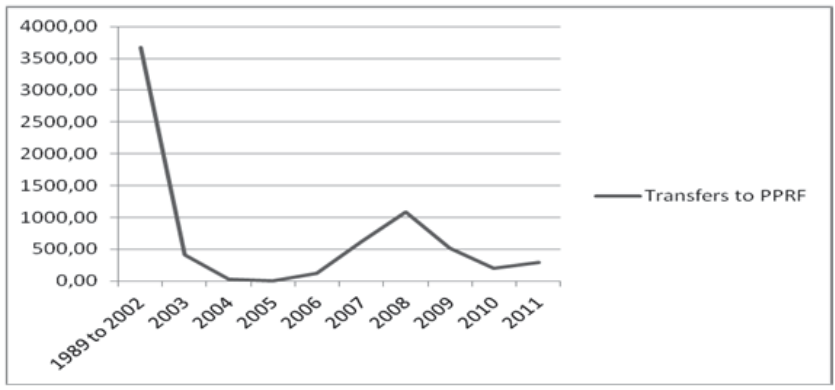

An analysis of the adopted governance model is due, given that ensuring the good governance of reserve funds is essential to meeting their goal of financing public pension systems. As mentioned earlier, the IGFCSS is the management entity of the public pension reserve fund. The governing body has grown over the years and has increased by 10 members. Table 5 presents the evolution of its organisation structure.

Table 5. Organisation Structure

\begin{tabular}{lcccccccccc}
\hline Function & 2000 & 2001 & 2002 & 2003 & 2004 & 2005 & 2006 & 2007 & 2008 & 2009 \\
\hline Senior Managers & 2 & 2 & 2 & 2 & na & na & na & na & 2 & 3 \\
\hline Managers & 1 & 4 & 5 & 4 & na & na & na & na & 3 & 3 \\
\hline Qualified Technical Personnel & 6 & 8 & 11 & 11 & na & na & na & na & na & \\
\hline Semi-Qualified Technical & 1 & 0 & 0 & 0 & na & na & na & na & na & 21 \\
\hline Administrative & 6 & 7 & 6 & 6 & na & na & na & na & na & na \\
\hline Auxiliary & 2 & 1 & 1 & 1 & na & na & na & na & 4 & 1 \\
\hline Total & 18 & 22 & 25 & 24 & 24 & 25 & 26 & 24 & $27 / 29$ & 28 \\
\hline
\end{tabular}

Source: Instituto de Gestão de Fundos de Capitalização da Segurança Social, Annual Reports (2001-2009). na - not available 
Table 6 shows asset allocation through the period of 1998-2011. Major shifts in investment strategy occurred with the decision to create the strategic reserve in 2002 and the expansion of allocations to private equity in 2004 (see Table3).

Table 6. Composition of the Fund Portfolio (\%), 1998-2011

\begin{tabular}{|c|c|c|c|c|c|c|c|c|c|c|c|c|c|c|}
\hline Assets & 1998 & 1999 & 2000 & 2001 & 2002 & 2003 & 2004 & 2005 & 2006 & 2007 & 2008 & 2009 & 2010 & 2011 \\
\hline Public Debt Securities & 73.16 & 73.34 & 56.49 & 51.01 & 51.45 & 52.32 & 53.66 & 50.51 & 50.29 & 50.45 & 55.90 & 50.56 & 53,17 & 50.67 \\
\hline Other Bonds & 7.72 & 14.66 & 23.68 & 29.77 & 30.13 & 22.53 & 20.60 & 17.65 & 19.82 & 19.62 & 21.47 & 27.33 & 18.41 & 11.88 \\
\hline Trust Units & 1.38 & 3.80 & 3.95 & 6.68 & 1.64 & 0.17 & 0.12 & 0.00 & 0.00 & 0.00 & 0.00 & 0.00 & 0.00 & 0.00 \\
\hline nares & 0.16 & .30 & 4.69 & 7.12 & 15 & 9.23 & 13.51 & 24.24 & 20.83 & 20.67 & 16.61 & 17.13 & 23,24 & 16.31 \\
\hline eal E & 0.32 & 0.52 & 89 & 0.71 & 1.56 & 1.43 & 1.78 & 2.99 & 3.58 & 3.20 & 2.95 & 2.31 & 2,20 & 2.31 \\
\hline $\mathrm{A} / \mathrm{Cs}$ & 17.27 & 6.38 & 10.30 & 4.49 & 7.20 & 11.20 & 7.12 & 1.62 & 2.19 & 2.91 & 1.07 & 0.39 & 0,80 & 17.34 \\
\hline Strategic Reserve & - & - & - & - & 2.87 & 3.10 & 3.19 & 2.98 & 3.30 & 3.16 & 1.99 & 2.27 & $2,17 \%$ & 1.46 \\
\hline otal (millions €) & 47. & 94 & 8 & 0 & 99 & 28. & 779. & 176. & 2040 & 56 & 338.8 & 07. & 370 & 872.4 \\
\hline
\end{tabular}

Source: Instituto de Gestão de Fundos de Capitalização da Segurança Social, Annual Reports (1998-2009); Conta da Segurança Social, 2011.

Portuguese State bonds constitute the largest proportion of investments, reflecting the legal obligation that not less than $50 \%$ of assets must be invested in such assets. The share made up of "Other Bonds" includes debt assets of other member states of the EMU and of private companies. In 2011, equities accounted for $16.31 \%$ of the portfolio, although the legal maximum is set at $25 \%$.

The new strategic reserve, which has been in operation since 2002, cannot represent more than $5 \%$ of total assets. By 2011, it represented $2.17 \%$ of the portfolio.

Management costs have been decreasing, contrasting with the increasing size of the organisation structure (Table 7) and salaries. Net income registered a prominent negative value in 2008.

Table 7. Management Costs and Profitability

\begin{tabular}{|c|c|c|c|c|c|c|c|c|c|c|c|c|}
\hline Indicators & 2000 & 2001 & 2002 & 2003 & 2004 & 2005 & 2006 & 2007 & 2008 & 2009 & 2010 & 2011 \\
\hline $\begin{array}{l}\text { Net Income } \\
\text { (million Euros) }\end{array}$ & 118 & 109 & 106 & 313 & 321 & 393 & 316 & 286 & -313 & 552 & na & na \\
\hline Management Costs (\%) & 0.044 & 0.0457 & 0.04871 & 0.0410 & 0.0404 & 0.03789 & 0.03248 & $0.03 \%$ & 0.029 & 0.028 & na & na \\
\hline $\begin{array}{l}\text { Transaction, Deposit \& } \\
\text { Commission Costs \& } \\
\text { Brokerage Fees }(\%) \\
\end{array}$ & 0.044 & 0.0311 & 0.02473 & 0.0264 & 0.0385 & 0.03101 & 0.02182 & 0.027 & 0.03 & 0.034 & na & na \\
\hline $\begin{array}{l}\text { Total Costs (\%) } \\
\text { (Costs/Amount under } \\
\text { management) }\end{array}$ & 0.088 & 0.0768 & 0.0734 & 0.0674 & 0.0789 & 0.0689 & 0.0543 & 0.057 & 0.059 & 0.062 & 0.054 & 0.049 \\
\hline $\begin{array}{l}\text { Salaries } \\
\text { (thousand Euros) }\end{array}$ & 947 & 858 & 1036 & 1208 & 1174 & 1183 & 1041 & 998 & 1003 & 1150 & na & na \\
\hline
\end{tabular}

Source: IGFCSS, Annual Reports 2000-2009; Conta da Segurança Social, 2010-2011.

Administrative costs are relatively low compared with other public pension reserve funds (OECD, 2009, 2011).

In 2006 and 2009, the management model of FEFSS won the Investments \& Pension Europe Award for the best pension fund in Portugal (see Table 3).

In 2009, a new strategic management policy was established which includes risk management indexation to EFFAS Portugal and the transition to a dynamical benchmark. However, since 2011 this has been abandoned, owing to the adverse financial conditions caused by the sovereign debt crisis that affected Portugal. The outbreak of the Greek financial crisis in 2009-2010 and the resulting transmission of difficulties in external financing to other countries, including Portugal, Ireland, and Spain, are among a number of events that led to large market movements (Araújo and Garcia, 2013). 


\section{Investment Returns}

Regarding investment performance, real rate of return has shown a growth trend from 2002 to 2006 . However, the average rate of return since the Fund's inception has been decreasing, reaching its lowest level in 2011 (see Table 8). Therefore, some lessons need to be learnt. One possible explanation may be the growing weight of equities in portfolio composition and the stock crash that was registered during 2000-2002 and since 2008. In addition, the Board of Directors should establish clear performance benchmarks in order to assess investment performance, since there is no clear measurable objective regarding rate of return. Annual benchmarking should be clearly established and the objective should be to seek to maximize long-term investments returns, whilst maintaining a prudent level of risk.

Table 8. Public Pension Reserve Fund Rates of Return

\begin{tabular}{lcccccccccccc}
\hline Indicators & 2000 & 2001 & 2002 & 2003 & 2004 & 2005 & 2006 & 2007 & 2008 & 2009 & 2010 & 2011 \\
\hline Nominal Rate of Return (\%)(Net of Tax \& Costs) & 4.11 & 3.28 & 2.51 & 6.50 & 5.90 & 6.76 & 5.18 & 4.08 & -3.86 & 6.25 & 0.08 & -11.00 \\
\hline Real Rate of Return (\%) (Net of Tax \& Costs) & 1.97 & 0.96 & 0.21 & 4.45 & 3.46 & 4.44 & 3.20 & 0.98 & -6.46 & 5.28 & -2.08 & -13.3 \\
\hline Average real rate of return since inception & 4.36 & 3.41 & 2.44 & 2.80 & 2.91 & 3.12 & 3.09 & 2.87 & 1.71 & 2.05 & 1.57 & -0.13 \\
\hline Excess return to the cost of public debt & na & na & na & na & n.a. & 0.05 & 0.72 & na & na & na & na & na \\
\hline
\end{tabular}

na - not available

Source: IGFCSS, Annual Reports, 2000-2008; Conta da Segurança Social, 2009-2011.

It is noticeable that the change of the Board of Directors is always accompanied by changing the Statutory Audit Entity (see Table 2). In addition, the Board of Directors that was appointed in 2005, is still in office (for nine years now), which gives rise to the question as to what is the limit for renewing mandates of the Board of Directors. Therefore there is a need to clearly stipulate the process for terminating a directorship in an act of law.

\section{Conclusion}

The aim of this study was to present the public pension system in its entirety and to analyse the functioning of public pension fund management. The creation of public pension funds in several countries gives rise to concern about the ability to ensure their independence and their insulation from political pressures. Hence, special emphasis should be placed on upgrading their investment policy guidelines and on strengthening their governance structure. Public pension funds have the potential to benefit from low operating costs, as they benefit from economies of scale and do not incur large marketing costs. However, this important advantage has been squandered by poor investment performance in most countries, on account of weak governance structures, the lack of independence from government interference, and a low level of transparency and public accountability. Therefore there is a need to promote a modern set of guidelines for efficient investment performance.

In conclusion, given the public reserve fund returns, a mixed system of capitalisation offers good perspectives for guaranteeing the financial sustainability of the Social Security system. In general, the Portuguese public pension reserve fund shows a good level of governance and has been a positive experience, but some weaknesses have been identified which highlight the need for reform. The annual reports lack transparency to a degree and make comparison difficult, which may be related to the duration of the mandate of the governing body. Pension policy reform is often challenging as it involves long-term decisions in the face of numerous short-term political pressures (Bonoli, 2003). Such reforms will ultimately improve the long-term investment performance of the funds and the solvency of the Social Security systems. Further research needs to be carried out on this subject.

\section{Acknowledgement}

UECE (Research Unit on Complexity and Economics) is financially supported by FCT (Fundação para a Ciência e a Tecnologia), Portugal. This article is part of the Strategic Project (Pest-OE/EGE/UI0436/2014). 


\section{References}

Araújo, A. and Garcia, M. T. M. (2013) Risk contagion in the north-western and southern European stock markets. Journal of Economics and Business, 69, 1-34.

Bonoli, G. (2003) Two Worlds of Pension Reform in Western Europe. Comparative Politics, 35, 4: 399-416.

Diamond, Peter A. (1996) Proposals to Restructure Social Security. Journal of Economic Perspectives-Volume 10, Number 3Summer 1996, Pages 67-88

Garcia, M. T. M. (2004) An Analysis of Pension Funds in Portugal. Pensions - An International Journal, Volume 9, Number 3, April, pp. 227-245.

Garcia, M. T. M. (2006) Individual Responsibility for the Adequacy of Retirement Income. Pensions - An International Journal, Vol. 11, No. 3, May, 192-199.

Garcia, M. T. M. and Lopes, E. G. (2009) Macro economic impact of reforming a PAYG system: the Portuguese case. International Social Security Review, Vol. 62, No1., 1-23.

Heise, Arne and Lierse, Hanna (2011) The Effects of European Austerity Programmes on Social Security Systems. Modern Economy, 2011, 2, 498-513.

Hess, David and Impavido, Gregorio (2004) Governance of Public Pension Funds: Lessons from Corporate Governance and International Evidence. Chapter 2.

Iglesias, A. and Palacios, R. J. (2000) Managing Public Pension Reserves. Part I: Evidence from the International Experience. SP Discussion Paper No. 0003, January.

Impavido, G. (2002) On the Governance of Public Pension Fund Management, The World Bank, 20th August.

Lindbeck, A. and Persson, M. (2003) The Gains from Pension Reform. Journal of Economic Literature. Vol. XLI, March, pp. 74-112.

OECD (2009) Pensions at a glance 2009: retirement-income systems in OECD countries - ISBN 978-92-64-06071-5 - C OECD 2009.

Orenstein, Mitchell A. (2013) Pension Privatization: Evolution of a Paradigm. Governance: An International Journal of Policy, Administration, and Institutions, Vol. 26, No. 2, April, pp. 259-281.

Palacios, Robert. (2002) Managing Public Pension Reserves Part II: Lessons from Five Recent OECD Initiatives. Social Protection Discussion Paper Series, No. 0219.

Silva, C. M. P., Calado, J. P. T., and Garcia, M. T. M. (2004) The Financial Sustainability of the Portuguese Social Security System. The Geneva Papers on Risk and Insurance, Vol. 29, No. 3, July, pp. 417-439.

Stewart, F. and J. Yermo (2010) Options to Improve the Governance and Investment of Japan's Government Pension Investment Fund. OECD Working Papers on Finance, Insurance and Private Pensions, No. 6, OECD.

Vittas, D., Impavido, G., and O'Connor, R. (2008) Upgrading the Investment Policy Framework of Public Pension Funds. Policy Research Working Paper 4499. The World Bank.

Yermo, Juan. (2007) Reforming the Valuation and Funding of Pension Promises. OECD Working Paper on Insurance and Private Pensions No. 13.

Yermo, Juan. (2008) Governance and Investment of Public Pension Reserve Funds in Selected OECD Countries. OECD Working Paper on Insurance and Private Pensions No. 15.

World Bank Policy Research Report (1994) Averting the Old Age Crisis, Policies to Protect the Old and Promote Growth, Oxford University Press. 